\title{
Biting and resting behaviour of malaria vectors in Bandar-Abbas County, Islamic Republic of Iran
}

Abdol Resoul Mojahedi, ${ }^{1}$ Reza Safari, ${ }^{1}$ Masood Yarian, ${ }^{2}$ Abbas Pakari, ${ }^{1}$ Ahmad Raeisi, ${ }^{2,3}$ Hamideh Edalat, ${ }^{2}$ Mojgan Beniardelan, ${ }^{2}$ Abbas Poudat, ${ }^{2}$ Morteza Zaim $^{2,4}$ and Hamid Reza Basseri

${ }^{1}$ Hormozgan County Health Center, Deputy of Health, Hormozgan University of Medical Sciences, Bandar Abbas, Islamic Republic of Iran. ${ }^{2}$ Department of Medical Entomology \& Vector Control, School of Public Health, Tehran University of Medical Sciences, Tehran, Islamic Republic of Iran (Correspondence to: H.R. Basseri: basserih@tums.ac.ir). ${ }^{3}$ Center for Disease Control, Malaria Control Section, Ministry of Health and Education, Tehran, Islamic Republic of Iran. ${ }^{4}$ Affiliated professor of School of Public Health, Tehran University of Medical Sciences, Tehran, Islamic Republic of Iran.

\begin{abstract}
Background: Blood feeding and resting behaviour of malaria vectors are the most influential factors in malaria transmission.

Aims: To measure blood feeding and resting behaviour, conventional mosquito sampling methods were performed in an area with potential for malaria transmission.

Methods: Adult mosquitoes were collected monthly from indoor/outdoor places by conventional sampling methods, and larval habitats were investigated. Enzyme-linked immunosorbent assay was used to measure the human blood index (HBI) of the mosquitoes.

Results: Anopheles stephensi, Anopheles culicifacies, Anopheles dthali and Anopheles fluviatilis, were collected. Overall, 1249 female Anopheles mosquitoes were captured on human and animal baits, but no human-vector contact occurred indoors. A. dthali, A. fluviatilis and A. culicifacies showed a greater tendency to outdoor resting places in contrast to A. stephensi, which had a propensity to indoor resting places. The seasonal biting activities of all species occurred at average temperatures between 23 and $27^{\circ} \mathrm{C}$. HBI was measured as $27.2 \%, 20.7 \%, 19.1 \%$, and $23.0 \%$ for A. fluviatilis, A. stephensi, A. culicifacies and A. dthali, respectively.

Conclusion: Vector control strategy depends upon mosquito behaviour. Therefore, using appropriate sampling methods based on mosquito behaviour is critical for malaria control planning. Exophilic/exophagic habit of mosquito vectors leads to fewer human bites, resulting in biting protection. Exophilic behaviour also requires specific larvicidal operations in order to prevent and control malaria transmission.

Keywords: Anopheles, Malaria, vector behaviour, ecology, Islamic Republic of Iran

Citation: Mojahedi AR; Safari R; Yarian M; Pakari A; Raeisi A; Edalat H. et al. Biting and resting behaviour of malaria vectors in Bandar-Abbas County, Islamic Republic of Iran. East Mediterr Health J. 2020;26(10):1218-1226. https://doi.org/10.26719/emhj.19.104

Received: 23/09/18; accepted: 26/02/19

Copyright @ World Health Organization (WHO) 2020. Open Access. Some rights reserved. This work is available under the CC BY-NC-SA 3.0 IGO license (https://creativecommons.org/licenses/by-nc-sa/3.o/igo)
\end{abstract}

\section{Introduction}

To eliminate malaria transmission from potential zones is a big challenge, and understanding vector biology and ecology play a major role in the battle against malaria (1). The emergence of new behavioural patterns of mosquitoes may significantly increase the risk for malaria transmission and represents a new challenge for malaria elimination (2). To combat malaria transmission and vectors it is necessary to understand the behaviour of the vector species. Spatial distribution of mosquitoes depends on environmental and climatological factors, so each species has its own range in a given area (3). As seasonal fluctut ations in vector populations act to synchronize disease transmission, the patterns of anopheline mosquito population dynamics provide important data for understanding the epidemiology and control of malaria (4). Howevv er, human and mosquito contact is a major challenge in malaria areas $(5,6)$.

The main malaria vector control tools are indoor residual spraying (IRS), and long-lasting insecticide- impregnated bednets. The correct use of these tools depends on mosquito biting and resting behaviour, as well as their susceptibility to the applied insecticides (7). Extensive and long-term use of chemicals in malaria vector control programmes leads to changes in vector behaviour (8).

Recently, the Islamic Republic of Iran reported fewer than 200 cases of malaria, which was confirmed based on the World Health Organization (WHO) classification (9). More than $90 \%$ of malaria cases were found in the south and southeast of the Islamic Republic of Iran, with a population of $\sim 746000$ (10).

Among 25 species of Anopheles reported in the Islamic Republic of Iran, 7 are considered to be malaria vectors, and five of them, Anopheles stephensi, Anopheles fluviatilis, Anopheles culicifacies, Anopheles dthali and Anopheles superpictus, are present within the south and southeast of the country (11-13). Although, no insecticide resistance has been reported among $A$. fluviatilis and A. dthali in Southern Islamic Republic of Iran, A. stephensi 
became resistance to dichlorodiphenyltrichloroethane (DDT), dieldrin and -cyhalothrin and tolerant towards deltamethrin $(12,14)$.

Hormozgan Province is one of the most important malaria transmission areas in Southern Islamic Republic of Iran. Malaria eradication and control programmes have failed to sustain the area free of malaria (15). Malaria incidence has significantly reduced during the past 2 decades in Hormozgan. However, like other areas located in Southern Islamic Republic of Iran, the crossborder movement of populations from malaria-endemic Pakistan and Afghanistan is considered tobe the main challenge for elimination of malaria in Hormozgan (16). Despite the risks of malaria transmission, mosquito bite protection and use of mosquito nets are not priorities among residents of the area (17). Hence, in the current study, we noted different behaviour of malaria vectors, in order to establish the key factors that have influenced disease transmission in a potential area. Based on the collected data, malaria elimination planning can be designed more efficiently.

\section{Methods}

\section{Study design}

This study was performed between September 2014 and August 2015 in Siaho District located about $90 \mathrm{~km}$ north of Bandar-Abbas County, Hormozgan Province (25 $24-$ $28^{\circ} 57 \mathrm{~N}$ and $52^{\circ} 41-59^{\circ} 15 \mathrm{E}$ ). The average Annual Parasite Index in the last 5 years was 0.18 in Hormozgan province. Siaho District has been malaria free for 5 years and vector control interventions are limited to larvicides and mosquito nets. Four malaria vectors exist in the area that allowed us to study their biting and resting behaviour. In addition, Siaho District is a potential area for malaria transmission but due to the strong healthcare system and early detection system, transmission of malaria has been hampered. The temperature reaches a maximum of $35^{\circ} \mathrm{C}$ in the highlands and $40^{\circ} \mathrm{C}$ in plain areas during the summer but it rarely declines to $5-10^{\circ} \mathrm{C}$ during winter.

Hormozgan comprises 3 regions of differing geography; the coastal region in the south, a mountainous region in the north, and a rural plateau or plain region located in the centre. Siaho District is a rural county located in the mountainous area with a total population of $>10000$. It is an agricultural region irrigated by rivers, deep wells and cement pools, which are the main breeding sites for mosquitoes. The annual rainfall ranges from 80 to $100 \mathrm{~mm}$. The main factor that contributes to perennial transmission is population movement; especially from the western border province, Sistan-Baluchistan.

\section{Entomological survey}

The survey was carried out twice a month, from September 2014 to August 2015. The area had no interventions for mosquito control during the study period. Mosquito collections were performed monthly according to the WHO guidelines (18). The sampling methods were pyrethrum space-spray catches from the indoors of 8 houses, and pit shelter collections from 2 artificial shelters. Human and animal landing catches and larvae were also collected by dipper or pipette. All methods were carried out twice a month. All samples were identified according to the morphological features. The abdominal conditions of female mosquitoes were recorded and blood meals of freshly fed females were smeared on Whatman filter paper, which was left to dry and kept at $? 20^{\circ} \mathrm{C}$ until use.

\section{Mosquito landing catch}

Blood feeding activity of malaria vectors was estimated by human landing catches on 2 baits, as well as animal landing catches. Human landing catches were carried out continuously during a whole night period from sunset to sunrise by trained staff using mouth aspirators. Two human volunteers from the native inhabitants acted as baits, while wearing their normal clothing. The exposed body surfaces were searched and the mosquitoes that were attempting to bite were collected using mouth aspirators by insect collectors. During human landing collections, collectors changed shifts every 2 hours. Animal landing catches were carried out on cows, as the dominant domestic animals, for wa hole night period as described above. The collected mosquitoes were kept and brought to the field laboratory alive to be identified. Finally, the human biting rate was calculated directly from human landing catches, based on the average number of bites per person or animal per night.

\section{Blood meal identification}

In order to identify human blood index (HBI), the blood meals of collected mosquitoes on Whatman filter papers were used for enzyme-linked immunosorbent assay (ELISA) as described previously (19). Each mosquito abdomen was ground in $50 \mathrm{ml}$ phosphate-buffered saline (PBS), and then $950 \mathrm{ml}$ PBS was added after grinding. Blood meals were identified by direct ELISA using anti-human IgG conjugated to alkaline phosphatase (Sigma, St. Louis, MO, United States of America) and proteins in a single-step assay. The results were assessed by naked eye examination and absorbance was measured with an ELISA reader at $405 \mathrm{~nm}$ about 30 minutes after addition of the substrate solution. The test wells were considered positive if they gave a visible yellow colour.

\section{Results}

A total of 1742 adult female mosquitoes were captured (Table 1). Most of them (71.7\%) were collected by landing catch methods on human (13.2\%) and animal (58.5\%) baits. The mosquitoes exhibited high exophagic behaviour and no indoor-biting mosquitoes were caught. A total of 590 larvae were collected. The adult mosquito species were A. stephensi (28.2\%), A. culicifacies (18.7\%), A. dthali (33.5\%) and A. fluviatilis (19.6\%). Regarding mosquitoes captured indoors, A. stephensi $(50.5 \%)$ was the dominant species captured from the indoor places. An. fluviatilis (33.7\%) and A. dthali (33.3\%) were the dominant species collected in outdoor shelters. The landing catch method was the most convenient to collect mosquitoes within the study area. 
Table 1 Total number of anopheline species (adults and larvae) collected using different methods in Siaho District, North of Bandar-Abbas, Hormozgan Province, September 2014-August 2015

\begin{tabular}{|c|c|c|c|c|c|c|}
\hline \multirow[t]{2}{*}{ Anopheles pecies } & \multicolumn{4}{|c|}{ Frequency of female mosquito captured by different sampling methods } & \multirow[t]{2}{*}{ Total } & \multirow{2}{*}{$\begin{array}{l}\text { No. of larvae } \\
\text { collected }\end{array}$} \\
\hline & $\begin{array}{l}\text { Spray sheet } \\
\text { collection }\end{array}$ & $\begin{array}{l}\text { Outdoor resting } \\
\text { collection }\end{array}$ & $\begin{array}{l}\text { Landing catch } \\
\text { collection on } \\
\text { human }\end{array}$ & $\begin{array}{l}\text { Landing catch } \\
\text { collection on } \\
\text { animal }\end{array}$ & & \\
\hline A. stephensi & 102 & 20 & 79 & 290 & 491 & 167 \\
\hline A. culicifacies & 31 & 76 & 29 & 190 & 326 & 120 \\
\hline A. dthali & 64 & 97 & 32 & 390 & 583 & 141 \\
\hline A. fluviatilis & 5 & 98 & 90 & 149 & 342 & 162 \\
\hline Total & 202 & 291 & 230 & 1019 & 1742 & 590 \\
\hline
\end{tabular}

Overall, $71.7 \%$ anopheles vectors were captured on baits including $82 \%$ on animal and $18 \%$ on human baits. Among them, A. dthali showed the greatest propensity for animal baits, as from 422 adult females, $92.4 \%$ of this species was captured on animal baits, while only $7.6 \%$ was found on human baits. In contrast, $37.7 \%$ of A. fluviatilis was captured on human baits. This indicated that, compared with A. dthali, A. fluviatilis had greater propensity for humans. Furthermore, from 369 females of A. stephensi and 219 females of A. culicifacies, $21.4 \%$ and $13.2 \%$ were collected on human baits, respectively.

The seasonal biting activities of all collected vectors depended on the seasonal temperature and declined during the winter (Figure 1). The highest biting activities of mosquitoes on humans occurred in April and May. Generally, seasonal prevalence of all malaria vectors (both indoors and outdoors) consisted of 2 major peaks (Figure 2). The maximum activities of mosquito populations occurred in spring, while the temperature was mild enough, although during winter (between January and February), the populations decreased to minimum density in indoor and outdoor resting places.
The population density of A. stephensi in indoor shelters was higher during the period of collection in comparison with outdoor locations. The monthly population density of A. fluviatilis in outdoors was higher when compared with that indoors. A. culicifacies and A. dthali used indoor and outdoor places alike (Figure 2).

The collected female mosquitoes were graded based on their abdominal condition (Table 2). The gravid and/ or half-gravid appearance of the abdomen represented the resting stages. The ratio of A. stephensi captured in the indoor places was noticeably higher than other species. Among all females mosquitoes collected in indoors, 50.5\% of them were A. stephensi and only $0.02 \%$ were A. fluviatilis. However, the high portion of A. stephensi females with gravid and half-gravid abdominal appearance was found in indoor places, indicating that these species prefer indoor resting places. In contrast, among the anopheles collected outdoors, almost $33.7 \%$ of them were A. fluviatilis, and $82.6 \%$ were blood fed or half gravid/gravid. HBI was $27.2 \%, 20.7 \%, 19.1 \%$, and $23.0 \%$ for A. fluviatilis, A. stephensi, A. culicifacies and A. dthali, respectively. Blood feeding of

Figure 1 Seasonal biting activity of anopheline vectors based on mean human-biting rate per night in Siaho District north of Bandar-Abbas County.

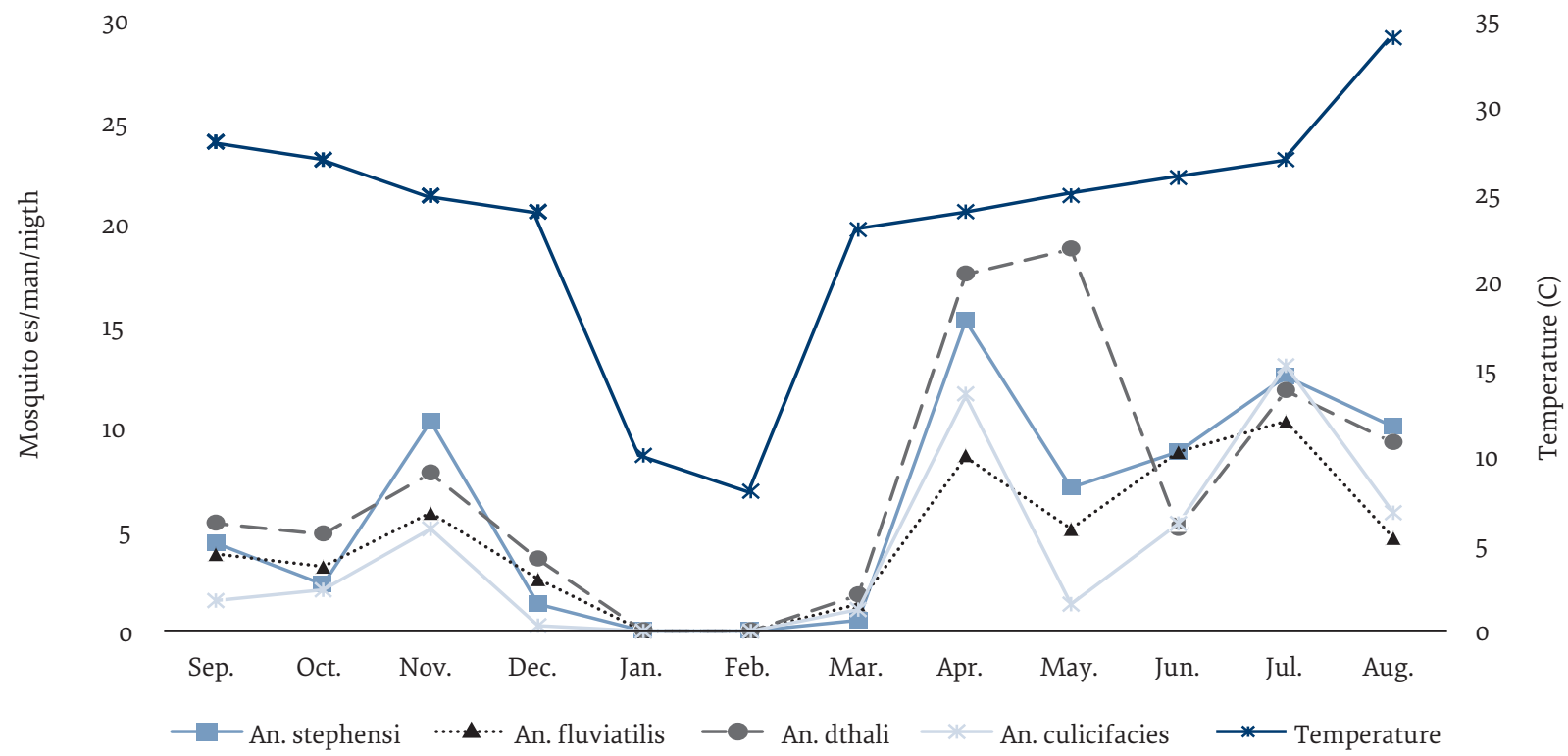


Figure 2 Comparing seasonal prevalence and resting behaviour of 4 main malaria vectors collected from indoor and outdoor places, Siaho, Bandar-Abbas.

25

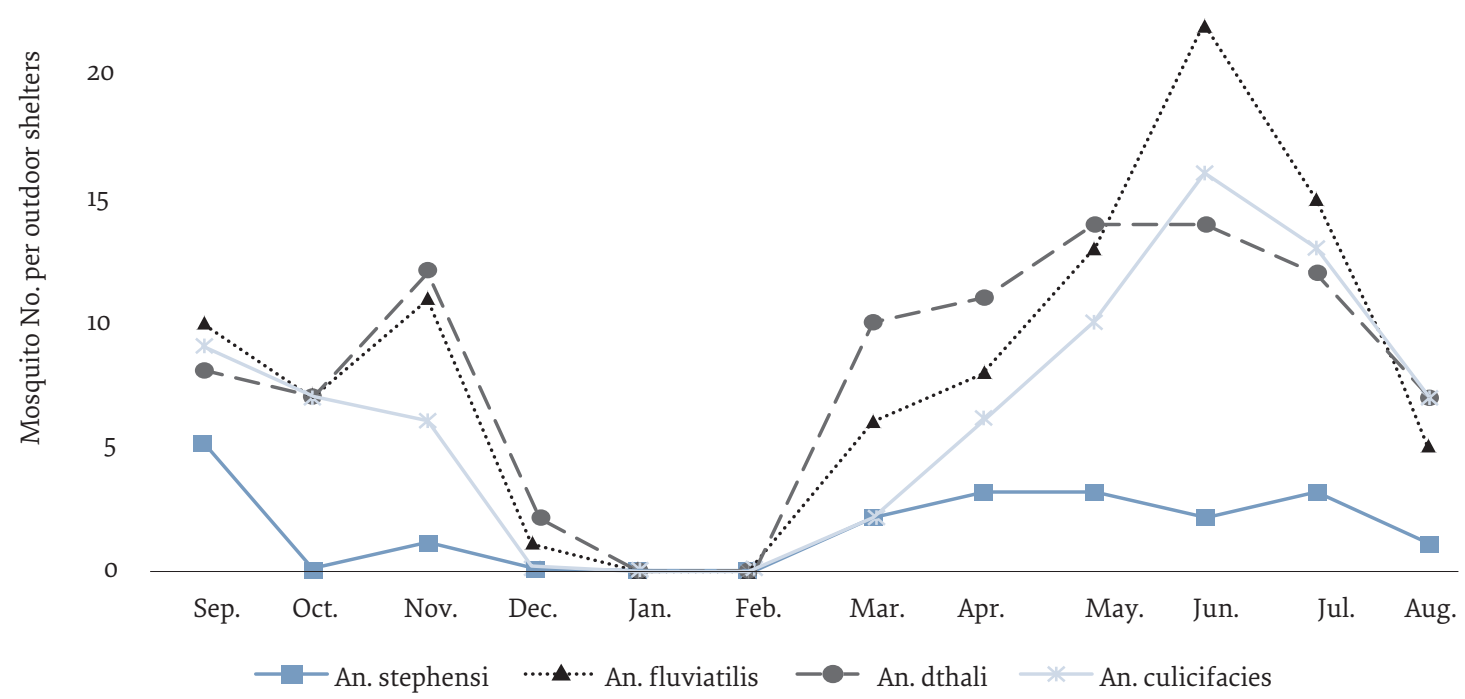

2.5

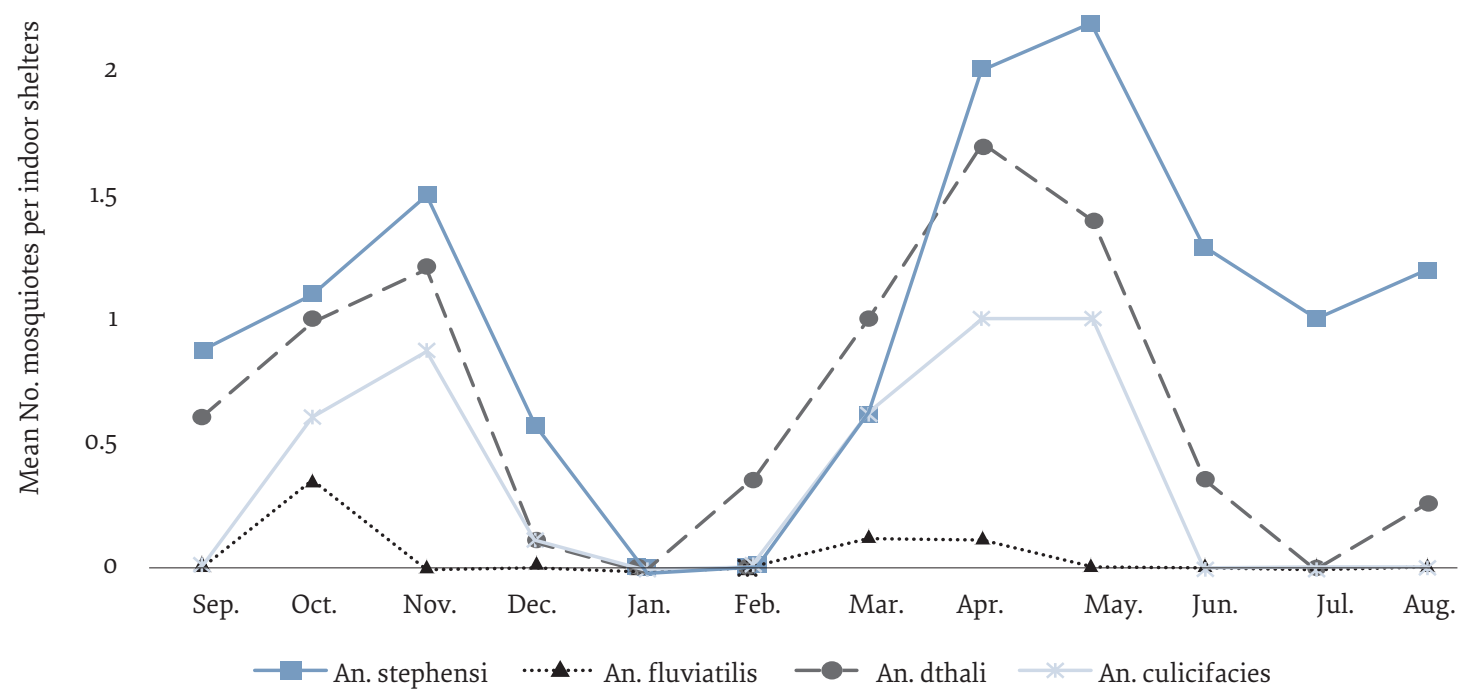

anopheline mosquitoes was mostly observed when the average monthly temperature was $23-27^{\circ} \mathrm{C}$.

The results of the larvae surveys are presented in Table 3. A total of 590 larvae were collected from different habitats. The larvae of A. fluviatilis mostly were found in clear water streams with sandy beds. A. stephensi $(100 \%)$ preferred non-vegetative stagnant water while A. dthali was mostly found in vegetative stagnant water. A. culicifacies also selected permanent stagnant water with/ without vegetation.

\section{Discussion}

Overall, all malaria vectors exhibited exophagic behaviour in the study area. The exophagic behaviour of $A$. fluviatilis, A. dthali and A. stephensi has been previously re- ported in Hormozgan province, Southern Islamic Republic of Iran $(20,21)$. At that time, IRS implementation was performed by the Malaria Eradication Program, but during the present study, although IRS was not used, some vectors such as A. culicifacies showed propensities to rest both inside and outside places. This indicates that IRS intervention may cause this vector to change to outdoors for rest; thus, IRS should be used more cautiously.

Endophilic and exophilic behaviour varied among the 4 vector species. While A. fluviatilis exhibited a highly exophilic tendency, A. stephensi showed more propensity towards the indoor shelters. Abundance of A. stephensi in indoor shelters confirms the previous finding of endophilic behaviour of this species in Southern Islamic Republic of Iran $(12,22)$. Similar findings have been 
Table 2 Ratio of female anopheline mosquitoes based on their abdominal appearance collected from indoor and outdoor shelters, Siaho District, Bandar Abbas, September 2014-August 2015

\begin{tabular}{|c|c|c|c|c|c|c|c|c|}
\hline \multirow[t]{2}{*}{ Anopheles species } & \multicolumn{4}{|c|}{$\begin{array}{c}\text { Indoor collection } \\
(\%)\end{array}$} & \multicolumn{4}{|c|}{$\begin{array}{l}\text { Outdoor collection } \\
(\%)\end{array}$} \\
\hline & UF & BF & G \& HG & Total & UF & BF & G \& HG & Total \\
\hline A. stephensi & $\begin{array}{c}14 \\
(13.7)\end{array}$ & $\begin{array}{c}27 \\
(26.5)\end{array}$ & $\begin{array}{c}61 \\
(59.8)\end{array}$ & 102 & $\begin{array}{c}5 \\
(25.0)\end{array}$ & $\begin{array}{c}7 \\
(35.0)\end{array}$ & $\begin{array}{c}8 \\
(40.0)\end{array}$ & 20 \\
\hline A. culicifacies & $\begin{array}{c}9 \\
(29.0)\end{array}$ & $\begin{array}{c}5 \\
(16.1)\end{array}$ & $\begin{array}{c}17 \\
(54.8)\end{array}$ & 31 & $\begin{array}{c}6 \\
(7.9)\end{array}$ & $\begin{array}{c}29 \\
(38.2)\end{array}$ & $\begin{array}{c}41 \\
(53.9)\end{array}$ & 76 \\
\hline A. dthali & $\begin{array}{c}15 \\
(23.4)\end{array}$ & $\begin{array}{c}12 \\
(18.7)\end{array}$ & $\begin{array}{c}37 \\
(57.8)\end{array}$ & 64 & $\begin{array}{c}24 \\
(24.7)\end{array}$ & $\begin{array}{c}55 \\
(56.7)\end{array}$ & $\begin{array}{c}18 \\
(18.6)\end{array}$ & 97 \\
\hline A. fluviatilis & $\begin{array}{c}1 \\
(20.0)\end{array}$ & $\begin{array}{c}0 \\
(00.0)\end{array}$ & $\begin{array}{c}4 \\
(80.0)\end{array}$ & 5 & $\begin{array}{c}17 \\
(17.3)\end{array}$ & $\begin{array}{c}46 \\
(46.9)\end{array}$ & $\begin{array}{c}35 \\
(35 \cdot 7)\end{array}$ & 98 \\
\hline
\end{tabular}

$\mathrm{BF}=$ blood fed; $G=$ gravid $; \mathrm{H} G=$ half gravid $\mathrm{UF}=$ unfed

reported from the neighbouring country of Pakistan $(23,24)$. All these studies found that the mosquitoes were collected from sites that had no insecticide intervention. The structure of shelters is important for A. stephensi. This species preferred thatched structures of cattle shelters due to the availability of eaves and crevices for resting and ageing (25). Furthermore, A. stephensi use household objects such as cupboards, furniture, hanging clothes, etc in the insecticide-sprayed villages (26). However, this species is mostly situated indoors, which is dependent on the seasonal temperature and structure of shelters and their availability for blood meal sources.

Seasonal blood-feeding behaviour of all anopheline mosquitoes partially depended on temperature and rainfall. Therefore, we found that the maximum human biting occurred in spring. As all 4 mosquito vectors showed outdoor-biting behaviour, it seems that the environment and weather of Siaho District provides conditions for vectors to exhibit this behaviour. Therefore, using mosquito nets ought to be a convenient method to protect inhabitants against malaria transmission.

We revealed the prevalence and predominance of $A$. fluviatilis in outdoor places. Slow running streams and stream channels around villages provide the favourite breeding places for A. fluviatilis to increase its population. Thus, identification of breeding places and high coverage of larvicidal operations is appropriate to keep the population of this mosquito low. Generally, these species have been reported as exophilic, with a high propensity for human blood in Southern Islamic Republic of Iran $(5,21,22,27)$. This species is widely distributed in the Indian Subcontinent, and exhibits a greater tendency to rest in human dwellings in Keonjhar and Chhattisgarh States $(28,29)$. In contrast, we found this mosquito mostly in outdoor shelters. It is noteworthy that the Indian species are mostly $S$ and $U$ of the Fluviatilis complex (30), while only the species $\mathrm{T}$ has been confirmed in Hormozgan Province (31). Therefore, the variation we observed regarding the resting behaviour of this species may have been due to the genetic difference in the population of A. fluviatilis complex, which requires more studies to be done. It is also possible that the environmental structure of the north of Bandar-Abbas (mostly at high temperature) caused the A. fluviatilis to display exophilic behaviour. The appropriate method to measure seasonal activity of this species is landing catch collection especially on animal bait. Previous studies have reported that A. fluviatilis has a high propensity for human blood $(5,20-22)$. In the current study, we also found it to be a highly anthropophagic species. The same behaviour has been reported among the A. fluviatilis complex in the Indian Subcontinent (32). Availability of human blood meal sources is dependent on house structure and resident behaviour but A. fluviatilis shows opportunistic feeding behaviour on human hosts, while resting outside for egg development (20). Thus, using mosquito nets, especially long-lasting insecticidetreated nets, is a convenient way to protect inhabitants and control this species in the study area.

A. dthali was reported for the first time as a malaria vector in Siaho in 1972 (13). Our study shows that this mosquito species is still predominant anopheles Siaho, north of Bandar-Abass County. However, > 45 years ago, it was reported that this species was predominant in the area $(20,21)$. This species was found at high density in indoor and outdoor places during seasonal activities. Generally, this species prefers hilly and valley-based areas. The presence of $A$. dthali in indoor as well as outdoor places indicates that the species can shift its resting places under any adverse conditions such as IRS. In the present study, the larvae of $A$. dthali were found in natural and vegetative water sources within reach of filamentous green algae. Similar habitats were described by Maffi in 1964 (33).

A. culicifacies is distributed in the Indian Subcontinent and extends from southeast of the Islamic Republic of Iran to Thailand and Vietnam (34). Previous studies from the north of Bandar-Abbas showed low occurrence of this species $(21,22)$ while in the current study, we found high abundance of this vector in the study area. This occurrence was most likely due to climate change that has an influence on global distribution of many mosquito species (35).

The current study also shows that anopheline blood feeding behaviour depends on seasonal temperature. Accordingly, the human-biting rate increases from 23 to $27^{\circ} \mathrm{C}$. The impact of environmental temperature is crucial 


\begin{tabular}{|c|c|c|c|c|}
\hline \multirow[t]{2}{*}{ Larval habitat } & \multicolumn{4}{|c|}{$\begin{array}{c}\text { No. of larvae } \\
(\%)\end{array}$} \\
\hline & A. stephensi & A. fluviatilis & A. dthali & A. culicifacies \\
\hline Permanent & $\begin{array}{c}157 \\
(94.0)\end{array}$ & $\begin{array}{c}162 \\
(100)\end{array}$ & $\begin{array}{c}141 \\
(100)\end{array}$ & $\begin{array}{c}108 \\
(90.0)\end{array}$ \\
\hline Temporary & $\begin{array}{c}10 \\
(0.6)\end{array}$ & $\begin{array}{c}0 \\
(0.0)\end{array}$ & $\begin{array}{c}0 \\
(0.0)\end{array}$ & $\begin{array}{c}12 \\
(10.0)\end{array}$ \\
\hline \multicolumn{5}{|l|}{ Habitat situation } \\
\hline Running water & $\begin{array}{c}0 \\
(0.0)\end{array}$ & $\begin{array}{c}133 \\
(82.1)\end{array}$ & $\begin{array}{c}23 \\
(16.3)\end{array}$ & $\begin{array}{c}0 \\
(0.0)\end{array}$ \\
\hline Stagnant water & $\begin{array}{c}167 \\
(100)\end{array}$ & $\begin{array}{c}29 \\
(17.9)\end{array}$ & $\begin{array}{c}118 \\
(83.7)\end{array}$ & $\begin{array}{c}120 \\
(100)\end{array}$ \\
\hline \multicolumn{5}{|l|}{ Vegetation situation } \\
\hline Vegetative & $\begin{array}{c}0 \\
(0.0)\end{array}$ & $\begin{array}{c}131 \\
(80.9)\end{array}$ & $\begin{array}{c}128 \\
(90.8)\end{array}$ & $\begin{array}{c}46 \\
(38.3)\end{array}$ \\
\hline Non vegetative & $\begin{array}{c}167 \\
(100)\end{array}$ & $\begin{array}{c}31 \\
(19.1)\end{array}$ & $\begin{array}{l}13 \\
(9.2)\end{array}$ & $\begin{array}{c}74 \\
(61.7)\end{array}$ \\
\hline \multicolumn{5}{|l|}{ Clarity } \\
\hline Clear & $\begin{array}{c}78 \\
(46.7)\end{array}$ & $\begin{array}{c}162 \\
(100)\end{array}$ & $\begin{array}{c}141 \\
(100)\end{array}$ & $\begin{array}{c}98 \\
(81.7)\end{array}$ \\
\hline Turbid & $\begin{array}{c}89 \\
(53 \cdot 3)\end{array}$ & $\begin{array}{c}0 \\
(0.0)\end{array}$ & $\begin{array}{c}0 \\
(0.0)\end{array}$ & $\begin{array}{c}22 \\
(18.3)\end{array}$ \\
\hline \multicolumn{5}{|l|}{ Water bed } \\
\hline Clay & $\begin{array}{c}65 \\
(38.9)\end{array}$ & $\begin{array}{c}0 \\
(0.0)\end{array}$ & $\begin{array}{c}0 \\
(0.0)\end{array}$ & $\begin{array}{c}0 \\
(0.0)\end{array}$ \\
\hline Sandy & $\begin{array}{c}70 \\
(41.9)\end{array}$ & $\begin{array}{c}97 \\
(59.9)\end{array}$ & $\begin{array}{c}70 \\
(49.6)\end{array}$ & $\begin{array}{c}45 \\
(37.5)\end{array}$ \\
\hline Cement & $\begin{array}{c}32 \\
(19.2)\end{array}$ & $\begin{array}{c}65 \\
(40.1)\end{array}$ & $\begin{array}{c}71 \\
(50.4)\end{array}$ & $\begin{array}{c}75 \\
(62.5)\end{array}$ \\
\hline \multicolumn{5}{|l|}{ Sunlight situation } \\
\hline Sunny & $\begin{array}{c}120 \\
(71.8)\end{array}$ & $\begin{array}{c}38 \\
(23.5)\end{array}$ & $\begin{array}{c}56 \\
(39.7)\end{array}$ & $\begin{array}{c}60 \\
(50.0)\end{array}$ \\
\hline Semi-sunny & $\begin{array}{c}25 \\
(14.2)\end{array}$ & $\begin{array}{c}74 \\
(45.7)\end{array}$ & $\begin{array}{c}45 \\
(31.9)\end{array}$ & $\begin{array}{c}36 \\
(30.0)\end{array}$ \\
\hline Shadow & $\begin{array}{c}20 \\
(12.0)\end{array}$ & $\begin{array}{c}48 \\
(29.6)\end{array}$ & $\begin{array}{c}40 \\
(28.4)\end{array}$ & $\begin{array}{c}24 \\
(20.0)\end{array}$ \\
\hline \multicolumn{5}{|l|}{ Type of habitat } \\
\hline Natural & $\begin{array}{c}143 \\
(85.6)\end{array}$ & $\begin{array}{c}162 \\
(100)\end{array}$ & $\begin{array}{c}141 \\
(100)\end{array}$ & $\begin{array}{c}107 \\
(89.2)\end{array}$ \\
\hline Artificial & $\begin{array}{c}24 \\
(14.4)\end{array}$ & $\begin{array}{c}0 \\
(0.0)\end{array}$ & $\begin{array}{c}0 \\
(0.0)\end{array}$ & $\begin{array}{c}13 \\
(10.8)\end{array}$ \\
\hline
\end{tabular}

for human-mosquito contact; thus, use of mosquito nets should be considered based on local temperature. Therefore, the average local temperature could be a helpful indicator for prediction of malaria transmission.

\section{Conclusion}

Biological variations in the vectors might complicate the control of malaria transmission, and vector control strat- egy depends on mosquito behaviour. Therefore, using appropriate sampling methods for mosquito behaviour must be considered as a critical factor for planning of malaria control. Exophilic/exophagic mosquito vectors lead to bite protection using mosquito nets as well as effective larval source management, which could provide an integrated vector management strategy in high-risk areas such as Hormozgan Province. 


\section{Acknowledgement}

The authors are grateful to the National Malaria Program, CDC/Ministry of Health, for supporting this study in all its process. Special thanks to the Deputy of Health, Hormozgan University of Medical Sciences, Bandar Abbas Health Research Station, and the Department of Medical Entomology \& Vector Control, School of Public Health, Tehran University of Medical Sciences, and the civilians of Siaho District for their support and collaboration throughout the different stages of this study.

Funding: This study was supported by the Deputy of Research, Tehran University of Medical Sciences, Grant No. 24210.

Competing interests: None declared.

\section{Comportement de piqûre et de repos des vecteurs du paludisme dans le comté de Bandar-Abbas (République islamique d'Iran)}

\section{Résumé}

Contexte: L'alimentation en sang et le comportement de repos des vecteurs de paludisme sont les facteurs de transmission les plus importants de la maladie.

Objectifs : Pour analyser les repas sanguins et le comportement de repos, on a utilisé des méthodes conventionnelles de collecte de moustiques dans une zone exposée au risque de transmission du paludisme.

Méthodes : On a prélevé tous les mois des moustiques adultes à l'intérieur et à l'extérieur des habitations en recourant à des méthodes conventionnelles de collecte et des gîtes larvaires ont été étudiés. Un essai d'immuno-absorption enzymatique (ELISA) a été utilisé pour mesurer l'indice d'anthropophilie des moustiques.

Résultats : Les espèces suivantes d'anophèles ont été collectées: Anopheles stephensi, Anopheles culicifacies, Anopheles dthali et Anopheles fluviatilis. Au total, 1249 moustiques anophèles femelles ont été capturés à l'aide d'appâts humains et animaux, mais aucun contact homme-vecteur n'a été recensé à l'intérieur des habitations. A. dthali, A. fluviatilis et A. culicifacies avaient davantage tendance à choisir des lieux de repos extérieurs, contrairement à A. stephensi, qui avait tendance à se reposer à l'intérieur des habitations. Pour toutes les espèces, les activités de piqûres saisonnières ont eu lieu à des températures moyennes comprises entre 23 et $27^{\circ} \mathrm{C}$. L'indice d'anthropophilie a été évalué à $27,2 \%$, à $20,7 \%$, à $19,1 \%$ et à $23,0 \%$ pour A. fluviatilis, A. stephensi, A. culicifacies et A. dthali, respectivement.

Conclusion: La stratégie de lutte antivectorielle dépend du comportement des moustiques. Par conséquent, il est essentiel d'utiliser des méthodes de collecte adaptées en fonction du comportement des moustiques pour la planification de la lutte antipaludique. L'exophilie et l'exophagie des vecteurs entraînent un nombre moins élevé de piqûres sur l'homme, ce qui se traduit par une protection contre les piqûres. Le comportement exophile nécessite également l'application de traitements larvicides particuliers pour prévenir la transmission du paludisme et lutter contre cette maladie.

$$
\begin{aligned}
& \text { سلوك اللدغ والر احة لنواقل الملاريا في مقاطعة بندر عباس بجمهورية إيران الإسلامية }
\end{aligned}
$$

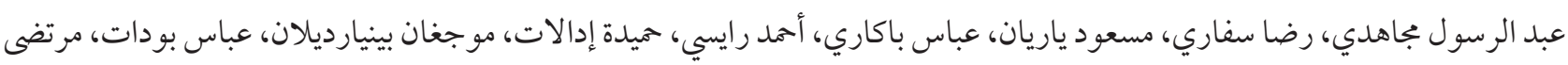

$$
\begin{aligned}
& \text { زعيم، حميد رضا بصيري } \\
& \text { الخلاصة } \\
& \text { الخلفية: يُعد سلوك الر احة وتغذية نو اقل الملاريا على الدم أكثر العوامل تأثيراً في انتقال الملاريا. } \\
& \text { الأهداف: هدفت الدراسة إلى قياس سلوك الراحة والتغذية على الدم باستخدام طرق تقليدية لأخذ عينات البعوض في منطقة يحتمل فيها انتقال } \\
& \text { الملاريا. } \\
& \text { طرق البحث: جرى جُع البعوض إلبالغ شهرياً من الأماكن المغلقة/ المفتوحة بطرق أخذا العينات التقليدية، كما جرى استقصاء موائل اليرقات. }
\end{aligned}
$$

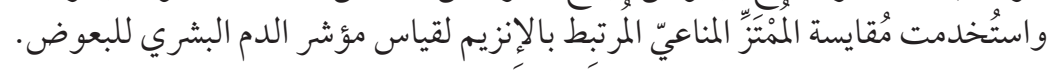




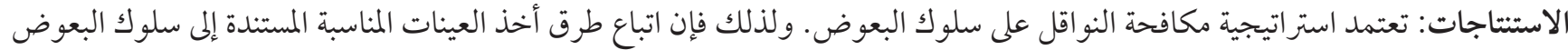

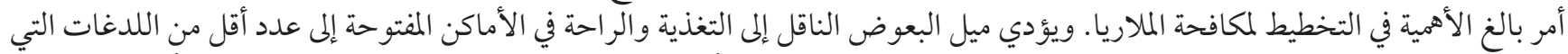

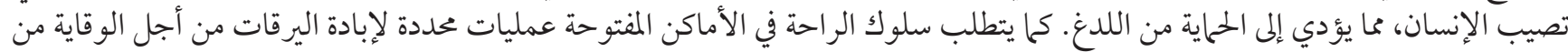
انتقال الملاريا ومكافحته.

\section{References}

1. Oaks SC, Violaine J, Mitchell S, Pearson GW, Carpenter CCJ. Malaria: obstacles and opportunities. Washington, DC: National Academy Press; 1991.

2. Kabbale FG, Akol AM, Kaddu JB, Onapa AW. Biting patterns and seasonality of Anopheles gambiae sensu lato and Anopheles funestus mosquitoes in Kamuli District, Uganda. Parasit Vectors. 2013 Dec 5;6:340. http://dx.doi.org/10.1186/1756-3305-6-340 PMID:24304974

3. Service MW, Townson H. The Anopheles vector. In: Gilles HM, Warrell DA, editors. Essential malariology. 4th ed. London: Arnold; 2002:59-84.

4. McKenzie FE, Killeen GF, Beier JC, Bossert WH. seasonality, parasite diversity, and local extinctions in Plasmodium falciparum malaria. Ecology. 2001;82(10):2673-81. http://dx.doi.org/10.189o/o012-9658(2001)082[2673:spdale]2.0.co;2 PMID:19177178

5. Basseri HR, Abai MR, Raeisi A, Shahandeh K. Community sleeping pattern and anopheline biting in southeastern Iran: a country earmarked for malaria elimination. Am J Trop Med Hyg. 2012 Sep;87(3):499-503. http://dx.doi.org/10.4269/ajtmh.2012.11-0356 PMID:22826491

6. Al-Eryani SM, Kelly-Hope L, Harbach RE, Briscoe AG, Barnish G, Azazy A, et al. Entomological aspects and the role of human behaviour in malaria transmission in a highland region of the Republic of Yemen. Malaria J. 2016 Mar 1;15:130. http://dx.doi. org/10.1186/s12936-016-1179-8 PMID:26932794

7. Osse RA, Aikpon R, Gbedjissi GL, Gnanguenon V, Sezonlin M, Govoetchan R, et al. A shift from indoor residual spraying (IRS) with bendiocarb to long-lasting insecticidal (mosquito) nets (LLINs) associated with changes in malaria transmission indicators in pyrethroid resistance areas in Benin. Parasit Vectors. 2013 Mar 16;6:73. http://dx.doi.org/10.1186/1756-3305-6-73 PMID:23497708

8. Boussari O, Subtil F, Moiroux N, Djenontin A, Iwaz J, Corbel V, et al. Modeling the seasonality of Anopheles gambiae s.s. biting rates in a South Benin sanitary zone. Trans R Soc Trop Med Hyg. 2014 Apr;108(4):237-43. http://dx.doi.org/10.1093/trstmh/tru027 PMID:24578284

9. World malaria report 2016. Geneva: World Health Organization; 2016 (https://apps.who.int/iris/bitstream/handle/10665/252038/9 789241511711-eng.pdf;jsessionid=CB78DD1AF27908816FE3D5A2C35D622E?sequence=1, accessed 27 December 2019).

10. Norouzinezhad F, Ghaffari F, Raeisi A, Norouzinejad A, Kaveh F. Malaria four-year epidemiological trends in Sistan and Baluchistan Province, Iran. Electron Physician. 2017 Jan 25;9(1):3660-4. http://dx.doi.org/10.19082/366o PMID:28243421

11. Azari-Hamidian S. Larval habitat characteristics of the genus anopheles (Diptera: culicidae) and a checklist of mosquitoes in guilan province, northern iran. Iran J Arthropod Borne Dis. 2011;5(1):37-53. PMID:22808409

12. Yeryan M, Basseri HR, Hanafi-Bojd AA, Raeisi A, Edalat H, Safari R. Bio-ecology of malaria vectors in an endemic area, Southeast of Iran. Asian Pac J Trop Med. 2016 Jan;9(1):32-8. http://dx.doi.org/10.1016/j.apjtm.2015.12.007 PMID:26851783

13. Manouchehri AV, Ghiasseddin M, Shahgudian ER. Anopheles dthali Patton, 1905, a new secondary vector in southern Iran. Ann Trop Med Parasitol. 1972 Dec;66(4):537-8. http://dx.doi.org/10.1080/00034983.1972.11686857 PMID:4571037

14. Zare M, Soleimani-Ahmadi M, Davoodi SH, Sanei-Dehkordi A. Insecticide susceptibility of Anopheles stephensi to DDT and current insecticides in an elimination area in Iran. Parasit Vectors. 2016 Nov 4;9(1):571. http://dx.doi.org/10.1186/s13071-016-1851-4 PMID:27809871 15. Edrissian GH. Malaria in Iran: past and present situation. Iran J Parasitol. 2006;1(1):1-14. http://ijpa.tums. ac.ir/index.php/ijpa/article/view/2

16. Basseri HR, Raeisi A, Holakouie K, Shanadeh K. Malaria prevention among Afghani refugees in a malarious area, southeastern Iran. Bulletin de la Societe de pathologie exotique. 2010;103(5):340-5. https://link.springer.com/article/10.1007\%2Fs13149-010-0050-3

17. Shahandeh K, Basseri H, Pakari A, Riazi A. Mosquito vector biting and community protection in a malarious area, siahoo district, hormozgan, iran. Iran J Arthropod Borne Dis. 2010;4(2):35-41. PMID:2280839

18. Manual on practical entomology in malaria. Geneva: World Health Organization; 1975

19. Edrissian GH, Manouchehry AV, Hafizi A. Application of an enzyme-linked immunosorbent assay (ELISA) for determination of the human blood index in anopheline mosquitoes collected in Iran. J Am Mosq Control Assoc. 1985 Sep;1(3):349-52. PMID:3880251

20. Eshghi N, Motabar M, Javadian E, Manoutcheri AV. Biological features of Anopheles fluviatilis and its role in the transmission of malaria in Iran. Trop Geogr Med. 1976 Mar;28(1):41-4. PMID:941241

21. Manouchehri AV, Djanbakhsh B, Eshghi N. The biting cycle of Anopheles dthali. A. fluviatilis and A. stephensi in southern Iran. Trop Geogr Med. 1976 Sep;28(3):224-7. PMID:1006791 
22. Basseri H, Raeisi A, Ranjbar Khakha M, Pakarai A, Abdolghafar H. Seasonal abundance and host-feeding patterns of anopheline vectors in malaria endemic area of iran. J Parasitol Res. 2010;2010:671291. http://dx.doi.org/10.1155/2010/671291 PMID:21559055

23. Herrel N, Amerasinghe FP, Ensink J, Mukhtar M, van der Hoek W, Konradsen F. Adult anopheline ecology and malaria transmission in irrigated areas of South Punjab, Pakistan. Medical and veterinary entomology. 2004 Jun;18(2):141-52. http://dx.doi. org/10.1111/j.0269-283X.2004.00481.x PMID:15189239

24. Rowland M, Mohammed N, Rehman H, Hewitt S, Mendis C, Ahmad M, et al. Anopheline vectors and malaria transmission in eastern Afghanistan. Trans R Socy Trop Med Hyg. 2002 Nov-Dec;96(6):620-6. http://dx.doi.org/10.1016/s0035-9203(02)90331-7 PMID:12625136

25. Thomas S, Ravishankaran S, Justin NA, Asokan A, Mathai MT, Valecha N, et al. Resting and feeding preferences of Anopheles stephensi in an urban setting, perennial for malaria. Malaria J. 2017 Mar 10;16(1):111. http://dx.doi.org/10.1186/s12936-017-1764-5 PMID:28283033

26. Nagpal BN, Srivastava A, Dash AP. Resting behaviour of Anopheles stephensi type form to assess its amenability to control malaria through indoor residual spray. J Vector Borne Dis. 2012 Sep;49(3):175-80. PMID:23135013

27. Maghsoodi N, Ladonni H, Basseri HR. Species composition and seasonal activities of malaria vectors in an area at reintroduction prevention stage, Khuzestan, South-Western Iran. Journal of arthropod-borne diseases. 2014 Jul 16;9(1):60-70. PMID:26114144

28. Nanda N, Bhatt RM, Sharma SN, Rana PK, Kar NP, Sharma A, et al. Prevalence and incrimination of Anopheles fluviatilis species S (Diptera: Culicidae) in a malaria endemic forest area of Chhattisgarh state, central India. Parasit Vectors. 2012 Sep 28;5:215. http:// dx.doi.org/10.1186/1756-3305-5-215 PMID:23021620

29. Rath A, Prusty MR, Das M, Mahapatra N, Tripathy H, Hazra RK. A shift in resting habitat and feeding behavior of Anopheles fluviatilis sibling species in the Keonjhar district of Odisha, India. Trans R Soc Trop Med Hyg. 2015 Nov;109(11):730-7. http://dx.doi. org/10.1093/trstmh/trv081 PMID:26464234

30. Chen B, Butlin RK, Pedro PM, Wang XZ, Harbach RE. Molecular variation, systematics and distribution of the Anopheles fluviatilis complex in southern Asia. Med Vet Entomol. 2006 Mar;20(1):33-43. http://dx.doi.org/10.1111/j.1365-2915.2006.00604.x PMID:16608488

31. Naddaf SR, Oshaghi MA, Vatandoost H. Confirmation of two sibling species among Anopheles fluviatilis mosquitoes in South and Southeastern Iran by analysis of cytochrome oxidase I gene. J Arthropod Borne Dis. 2012 Dec;6(2):144-50. PMID:23378972

32. Parida SK, Hazra RK, Marai N, Tripathy HK, Mahapatra N. Host feeding patterns of malaria vectors of Orissa, India. J Am Mosq Control Assoc. 2006 Dec;22(4):629-34. http://dx.doi.org/10.2987/8756-971X(2006)22[629:HFPOMV]2.0.CO;2 PMID:17304929

33. Maffi M, World Health Organization. Contribution to knowledge of the anopheline fauna of Mauitania. Geniva: WHO; 1964 (https://apps.who.int/iris/handle/10665/65167, accessed27 December 2019).

34. Sinka ME, Bangs MJ, Manguin S, Chareonviriyaphap T, Patil AP, Temperley WH, et al. The dominant Anopheles vectors of human malaria in the Asia-Pacific region: occurrence data, distribution maps and bionomic precis. Parasit Vectors. 2011 Dec 3;4:89. http://dx.doi.org/10.1186/1756-3305-3-117 PMID:21129198

35. Klinkenberg E, Konradsen F, Herrel N, Mukhtar M, van der Hoek W, Amerasinghe FP. Malaria vectors in the changing environment of the southern Punjab, Pakistan. Trans R Soc Trop Med Hyg. 2004 Jul;98(7):442-9. http://dx.doi.org/10.1016/j.trstmh.2003.11.007 PMID:15138083 